\title{
A Study of Iranian EFL Learners' Autonomy Level and its Relationship with Learning Style
}

\author{
Mojgan Nematipour \\ English Department, Faculty of Humanities, Islamic Azad University, Shiraz Branch, Iran \\ E-mail: Nematipour.mojgan@yahoo.com
}

Received: February 16, 2012

Accepted: May 10, 2012

Online Published: June 15, 2012

doi:10.5430/elr.v1n1p126

URL: http://dx.doi.org/10.5430/elr.v1n1p126

\begin{abstract}
Foreign language learning has become an essential component in people's lives over the past decades. Knowing the importance of students learning style, autonomy level and their impact on learning helps teachers take into consideration such factors when choosing the appropriate techniques and tasks for their lessons. This study investigated learners' autonomy level and its relationship with learning style in a sample of 200 undergraduate students studying at the Department of Foreign Languages, of Azad University, in Shiraz Branch by means of two questionnaires. The data of the study were analyzed by a two-way ANOVA and Pearson Product Moment Correlation with SPSS Version 16.0. The results revealed that visual and auditory learning styles were significantly and positively related to their learner autonomy. However there were no significant differences among males and females regarding language learning style and autonomy level.
\end{abstract}

Keywords: Learner autonomy, Levels of autonomy, Language learning style, Learning style dimensions

\section{Introduction}

The literature linking specific learning styles to learners' level of autonomy is not easy to find. The more typical target-language studies are those that have taken a broad pass at describing styles, a similar broad pass at describing learners' autonomy level, and have arrived at broad conclusions.

\subsection{Learner Autonomy}

Since language learning has become an essential component in people's lives, educational research has emphasized the need for students to take responsibility for their own learning. It goes without saying that this shift of responsibility from teachers to learners is the result of changes in the curriculum towards a more learner-centered learning. Thus, in order to contribute to the development of learner-centered education in language classrooms, it is vital that students be involved in taking control of their own learning.

Most educators and thinkers agree that autonomy should be taken as a desirable educational aim in order for students to master the new language. In this respect, many conceptions have been proposed and many educators have tried to explain learner autonomy. To define autonomy, we might quote Holec (1981: 3, cited in Benson \& Voller, 1997: 1) who considers it as "the ability to take charge of one's learning". Little (1991) also defines learner autonomy as "essentially the matter of the learners' psychological relation to the process and content of learning, a capacity for detachment, critical reflection, decision-making and independent action". In this respect, Candy (1991) stated autonomy "is learned at least partly through educational experiences [and interventions]" (Candy, 1991: 115). To develop this point, Littlewood (1996: 97) defined autonomy as "learners' ability and willingness to make choices independently". He also suggested that: "ability depends on possessing both knowledge about the alternatives from which choice have to be made and necessary skills for carrying out whatever choices seem most appropriate. Willingness depends on having both the motivation and confidence to take responsibility for the choices required" (Littlewood, 1996: 97).

\subsection{Language Learning Styles}

Learning style took its name in the 1970s. The origin of this concept has been attributed differently by scholars to individual differences, to the idea of "life styles" and to personality types (Zhang \& Sternberg, 2005). The idea of learning style is by no means a new element in the history of education. Over the past three decades, numerous studies were done on learning styles. (Lewis, 2008; McCann, 2006; Cano, 1999; Reid, 1987; Oxford, 1995; Wang, 
2007). Many educators tried their best to define language learning style. "These definitions range from concerns about preferred sensory modalities (e.g., visual, auditory, tactile, etc.) to descriptions of personality characteristics that have implications for behavior patterns in learning situations (e.g., the need for structure versus flexibility). Others have focused attention on cognitive information processing patterns" (Smith \& Renzulli, 1984: 45). For example, Keefe (1979) defined the notion of learning style as characteristic, cognitive, affective, and psychological behaviors that serve as stable indicators of how learners perceive, interact with and respond to the learning environment. According to Dunn and Griggs (1988), "learning style is biologically and developmentally imposed set of personal characteristics that make the same teaching method wonderful for some and terrible for others." (p. 3). Accordingly, many educators believe learners' learning styles have an impact on their academic performance. Perry (1970), for instance, stated that a basic progression in ways of thinking for a student during the college experience existed. Perry (1970) further stated that this basic progression influenced the instructor to seek other ways to teach based on student's learning style. Another example would be that of Rossi-Le who examined the relationship between the learning styles of 147 ESL learners and their chosen strategy use. The investigator reported that learners who preferred the visual mode chose visualization as a strategy, and those who preferred tactile and kinesthetic perceptual learning styles reported themselves as becoming directly involved with the subject matter being learned.

\subsection{Language Learning Styles and Learner Autonomy}

It is worth mentioning that a number of educators studied the relation between learner autonomy and language learning style. In a study conducted by Foen (2009), for instance, the analysis revealed that the number of learning styles, perceived learning environment and computer technology experience were statistically predictive of learner autonomy or distance learners' intention to participate. In anothe study conducted by Güven and Sünbül (n.d) at Selçuk University, the relation between the learners' autonomy level and their learning styles was examined. The results revealed that 1 . The participants usually preferred the Active Experimentation and Reflective Observation learning styles. 2. The average autonomy level of the participants was quite high. 3. There was no significant difference between the genders in relation to their learning styles and autonomous learning preferences 4 . Participants with reflective observation learning style had less autonomy in learning while the ones with active experimentation had the most. The results of a study performed by Gültekin and Karababa (2010) indicated that students' level of autonomy was not high and that there was a relationship between language learning styles and the autonomy level of the learners at Ankara University. Based on the research mentioned, it is clearly seen that there are different relationships between learners' autonomy level and their learning style in different contexts. Therefore, there is a need to investigate the styles employed by Iranian EFL university students in Iranian context. This study aims to see whether there is a relationship between styles employed by learners and their autonomy level. It is hoped that the results will contribute to our understanding of autonomy and help us select the styles that will lead to more autonomy among Iranian EFL learners.

\subsection{Gender, Learning Styles}

Reid (1987), in a study, concluded that there was a difference in the use of tactile learning style category between males and females with males being more tactile than females. Maubach and Morgan (2001) maintained that males and females were different regarding their learning style preferences; males were more willing to take risks and speak spontaneously. They were also self-confident about asking questions to aid their own understanding, whereas the female students were more interested in reading and presenting well-organized written work.

\section{Theoretical Framework}

\subsection{Language Learning Styles}

For the purpose of the present study, Felder-Silverman Model (Felder \& Silverman, 1988) was used. It is worth mentioning that Sharp (2001) describes an instructional module based on Felder-Silverman Model that makes students aware of differences in learning styles and how they may affect personal interactions, teamwork, interactions with professors, and learning difficulties and successes. Felder-Silverman Model was adopted for the present study because it has been found to be closely related to the Perceptual Learning Style Questionnaire conducted in the present study, including language-learning styles used in this research.

\subsection{Learner Autonomy}

Some researchers drew largely on Vygotskyan framework in Learning Autonomy. Ushioda (1996), for instance, contributed to the field of autonomy by placing the idea within a Vygotskyan theoretical framework. Some other researchers also drew largely on Vygotskyan framework. Oxford's (2003) revision to Benson's (1997) model of autonomy refers to approaches based on Vygotskyan learning theory, in which social environment comes to the 
foreground. The items in Learner Autonomy Questionnaire utilized in this study ranged from dependant problem solving to independent problem solving, which is in line with the Vygotskian concept of learning development. Thus the theoretical framework adopted for the present study is Vygotskian in nature.

\section{Research Methodology}

This is a descriptive study based on a survey research conducted for the purpose of making descriptive assertations about some population. This study aims at finding out the major, minor and negligible learning style preferences, the learning autonomy level, and to investigate the relationship between the learning style and learners' autonomy level at the Department of Foreign Languages in Azad University, Shiraz Branch. In this study quantitative data was collected. The data was collected through two questionnaires, one of which aimed to identify students' learning style preferences and the other aimed to investigate learners' autonomy.

\subsection{Participants}

The participants of this study were 200 undergraduate students studying at the Department of Foreign Languages in Shiraz Azad University. They were majoring in Teaching English as a Foreign Language (TEFL) and Translation at the Department of Foreign Languages. There was a total sample of 200 students in 6 classes. Since the participants' mother tongue was Persian, junior and senior students were chosen who had more exposure to the English language. Students had different educational backgrounds, but they had all passed more than 70 courses in English and were proficient enough to understand and answer the items in the original questionnaires. Their ages ranged from 19 to 25 years old. The proportion of male and female students in the classes was not equal. Not all of the undergraduate students took part in the study. A simple random sampling technique was used to choose 200 participants for this study. In order to examine the gender effect on participants' autonomy level and learning styles, both male and female learners were asked to participate in this study. Of all the 200 participants, 63 were male and 137 were female.

\subsection{Instrument}

In this research, two instruments were used. The Perceptual Learning Style Preference Questionnaire (PLSPQ) developed by Reid (1987) (see Appendix A), was used to explore the learning style preferences of the students. It is a self-reporting questionnaire developed on the basis of existing learning style instruments, with modifications suggested by non-native speakers and U.S. consultants in the fields of linguistics, education, and cross-cultural studies (Reid, 1987).The questionnaire consists of randomly arranged sets of 5 statements on each of the six learning style preferences (visual, auditory, kinesthetic, tactile, group learning, and individual learning). A Learner Autonomy Questionnaire (see Appendix B) developed by Zhang and Li (2004, p. 23), was also administered to see how autonomous the participants were in learning English as a foreign language. The questionnaires had been proved to have high content validity and high reliability

\subsection{Data Analysis}

The statistical analyses were conducted by using the Statistical Package for Social Sciences (SPSS). Regarding the analysis of the results obtained from the PLSPQ, descriptive statistics was used to group the students according to their major, minor, and negligible learning style preference categories. However only major and minor learning styles were used in the analysis, the descriptive statistics related to them were obtained in order to identify learners' learning styles regarding both major and minor learning style preferences. In order to investigate whether there was a match or mismatch between the learners' autonomy level and their learning style preference the Pearson Product Moment Correlation was used. And the relation between learners' learning style, autonomy level and gender was calculated through two-way ANOVA.

\section{Results}

\subsection{The Perceptual Learning Style Questionnaire Results}

The researcher used the Perceptual Learning Style Questionnaire developed by Reid (1987) in order to assess the students' learning style preferences. The questionnaire covers 30 questions in order for the researcher to diagnose the major, minor and negligible learning style preferences of students.

The frequency and percentage of major learning styles are presented in Table 1. It presents the most frequently used style to the least frequent one. Kinesthetic learning style is the most frequent $(26.5 \%)$ while the least frequent learning style is tactile (11\%). The styles in between are visual (17.5\%), individual (16\%), group (15.5\%) and auditory (13.5\%) respectively. 
Minor learning style preferences among the same learners and the related statistics are presented in Table 2. The results show that $27.5 \%$ of the participants under study can be characterized as kinesthetic minor learners, while $20.5 \%$ of individuals are shown to prefer visual learning style. $17.5 \%$ of learners are auditory learners. Group and tactile learners each make up $12.5 \%$ and $12.0 \%$ of the population respectively, which are more and less the same. And finally $10.0 \%$ of the participants are characterized as individual learners. According to the descriptive statistics in Table 2., most learners (nearly half of them) prefer kinesthetic and visual learning styles as minor learning style.

\subsection{The Learner Autonomy Questionnaire}

As is shown in Table 3, regarding the median score of the participants' autonomy questionnaire, the mean score of the low level learners is 64.6082 with a standard deviation of 6.22283 , meanwhile their scores range from 44 to 71 . The average score of the high level students is 77.9778 with the standard deviation of 4.15967 , and their scores vary from 73 to 93.

\subsection{Relation between Learners' Autonomy Level, their Language Learning Style Preferences and Gender.}

Two-way ANOVA results reported in Table 4. show no significant gender or autonomy level effect on participants' learning style preferences. As can be seen, the significance values for all six learning style types were bigger than the level of significance (.05). Therefore, the null hypotheses were retained. Thus, according to Table 4., there were no statistically significant differences between boys and girls with regard to their learning style preferences and autonomy.

\subsection{Relation between Learners' Autonomy and their Language Learning Style Preferences in high and low group.}

In view of the results given in the table 5, there is a positive and significant relation between autonomy and visual learning style preference in the high group. In addition, there is a positive and significant relation between the ones who preferred auditory learning style and their learning autonomy level in the same group, that is, they prefer autonomous learning. As regards the other styles, there wasn't any significant relation between the learning style preferences and learning autonomy level of the participants.

The results of the correlational analysis between different learning styles and autonomy in the low group are displayed in Table 6. As can be seen, the significance values of visual, auditory, kinesthetic, tactile, group and individual learning styles with respect to the low level autonomy are $.011, .040, .108, .051, .526$, and .944 respectively. Since the $p$ values are all bigger than .05 , there is no significant relation between the said variables.

\section{Discussion and Conclusion}

This study has provided a rich source of information on students' autonomy level regarding their learning styles and gender. It focuses on the notion that autonomy is a matter of degrees. It also contributes to the understanding of individuals' learning style differences and the relation between learners' autonomy level and their learning style preferences.

One major finding of this study was that Iranian learners make use of all six style preferences used in this study. According to descriptive statistics, it can be concluded that regarding both learning style groups, the most preferred learning styles among Iranian EFL learners are kinesthetic and visual learning styles. The finding of this study is partly parallel with studies performed by Ramli (2008) and Reid (1987). Ramli (2008), for instance, was found that the most preferred learning style of the students was kinesthetic style. The results of a study by Reid (1987) showed that ESL students strongly preferred kinesthetic and tactile learning styles.

Results showed that most participants believed in their abilities in learning English, they were studying English due to their own interest, they thought their success and failure were due to their attempt, and they preferred pair and group work (questions number 1, 12, 14, and 16, with mean scores of 4.29, 4.32, 4.08 and 4.02 respectively ). On the other hand, they did not like to preview lessons before class, keep record of their study, prepare self exams and reward themselves due to their success (questions number 3, 5, 6, and 7, with the lowest mean scores of 2.85, 2.94, 2.52 and 2.67 respectively) which are smaller than 3.0. The other questions showed the students' moderate autonomy among 21 questions Thus, regarding the overall mean value of 3.386 it can be concluded that most of the undergraduate EFL learners are moderately autonomous.

One important conclusion that could be drawn from this study is that although the author suspected that males and females may have different educational experiences, language learning style was not correlated with gender significantly and both male and female subjects subscribed to the same learning style preferences. The point that needs to be mentioned here is that the current research results show that there is no significant relationship between learning autonomy and gender either. 
In order to examine whether there is a relation between learners' autonomy level and their learning style preferences, Pearson Product Moment Correlation was conducted. The results showed that there were merely two statistically meaningful relationships between the participants' autonomy level (high and low) and their six learning style preferences of the two genders. The results revealed that the visual and auditory learning style preferences had a significant relationship with high level autonomy at $p<.05$ and the correlation coefficients were .268 and .217 respectively. The results obtained from this study seem to be partly congruent with the findings of the study conducted by Gültekin and Karababa (2010) which revealed that there was a relationship between language learning styles and the autonomy level of the learners. Gültekin and Karababa (2010) also indicated that students' level of autonomy at Ankara University was not high and that there was a relationship between their level of autonomy and learning styles.

As a conclusion, it can be said that investigating learning autonomy level and learning styles from the aspects of curriculum, teaching process and teachers will contribute significantly to the Iranian Education. In addition, the research carrried out on the relation between these variables and the students' gender might help the educational system to work more efficiently.

\section{Pedagogical Implications}

The varied distribution of learning styles among learners implies the following points:

1) In preparing teaching materials and programs, attention should be paid to learning styles and learning autonomy level and a broad range of teaching techniques should be employed so that the different learning preferences are catered for.

2) Students should be made aware of their learning style preferences in order to understand the materials better.

3) When planning curriculums, it is sensible to recognize the students' learning styles and their autonomy level.

4) Since the educators who are aware of the different learning style preferences are able to underestand how learners receive information and gain knowledge, it is imperative for teachers to have a sense of understanding of learning styles and autonomy levels among learners in different contexts in order to serve students' needs more efficiently.

\section{References}

Benson, P. (1997). The philosophy and politics of learner autonomy. In Benson \& voller. (eds.), 111-117.

Benson, P. \& Voller, P. (1997). Autonomy and Independence in Language Learning. London: Longman.

Cano, J. (1999). The relationship between learning style, academic major, and academic performance of college students. The Ohio State University: journal of Agricultural education vol.40.

Candy, P. C. (1991). Self-direction for Lifelong Learning. California: Jossey-Bass

Dunn, R. \& Griggs, S. (1988). Learning Styles: Quiet Revolution in American Schools. Reston, VA: National Association of Secondary School Principals.

Fedler, R.M,. \& Silverman, L.K. (1988). Learning and Teaching Styles in Engineering Education. Engr. Education, 78(7), 674-681.

Foen, N.S. (2009). Learning autonomy and some selected correlates among adult distance learners in Malaysia. Submitted to the School of Graduates Studies, University Putra Malaysia, in Fulfillment of the Requirement for the Degree of Doctor of Philosophy.

Gültekin, İ. \& Karababa, Z.C. (2010). The Relation between the autonomy level and the learning styles of English language learners. Ankara University Turkey. EABR \& ETLC Conference Proceedings Dublin, Ireland.

Güven, Z., \& Sünbül, A.M. (n.d). The Relation Between the Learners' Autonomy Level and Their Learning Styles. Selçuk University, Faculty of Education, Educational Sciences Department. International conference on quality in education in the Balkan countries, 8th - Saturday 11th November, 2007, Selanik - Greece.

Holec, H. (1981). Autonomy in Foreign Language Learning. Oxford: Pergamon. (First published 1979, Strasbourg: Council of Europe.).

Jiménes Raya, M. (2009). Pedagogy for autonomy in modern language education: The Euro PAL contribution. Learner autonomy in language learning. University of Granada, Spain.

Keefe, J. W. (1979). Learning style: An overview. In J. W. Keefe (Ed.) Student learning styles: Diagnosing and prescribing programs (pp.1-17). 
Lewis, N. (2008). The relationship between learning style and student success in a distance education program. Submitted to the Athabasca University Governing Council in partial fulfillment of the requirements for the degree of master of distance education.

Little, D. (1991). Learner autonomy: Definitions, Issues, Problems. Dublin: Authentic.

Littlewood, W. (1996). Autonomy: an anatomy and a framework. System, 24:4, 427-435. http://dx.doi.org/10.1016\%2FS0346-251X\%2896\%2900039-5

Maubach, A.M., and Morgan, C. (2001). The relationship between gender and learning styles amongst A level modern languages students. Language Learning Journal. No 23, 41-47. http://dx.doi.org/10.1080/09571730185200081

McCann, B.M. (2006). The relationship between learning style, learning environment, and student success. Journal of Agricultural education Volume 47, Number 3, 14-23.

Oxford, R.L. (1995). Gender differences in language learning styles: What do they mean? In J. M. Reid (Ed.) Learning styles in the ESL/EFL classroom (pp. 34- 46). New York: Heinle and Heinle Publishers.

Oxford, R. L. (2003). Toward a more Systematic model of L2 learner autonomy. In Palfreyman and Smith (eds.), 183-200.

Perry, W. G., Jr. (1970). Forms of intellectual and ethical development in the college years: a scheme. Orlando, FL: Harcourt Brace Jovanovich, Inc.

Ramli, N.H.B. (2008). A comparative study on the learning styles of second year education (living skills) students and the teaching styles of their lecturer. University Technology Malaysia. As the requirement for the Bestowal of bachelor of science and education. (TESL).

Reid, J., (1987). The learning style preferences of ESL students. TESOL Quarterly, 21, 87-111. http://dx.doi.org/10.2307\%2F3586356

Sharp, J.E. (2001). Teaching Teamwork Communication with Kolb Learning Style Theory, Proceeding, 2001 Frontiers in Education Conferefnce, Washington, D.C.: ASEE/IEEE.

Smith, L. H., \& Renzulli, J. S. (1984). Learning style preferences: A practical approach for classroom teachers. Theory into Practice, 23, 44-50. http://dx.doi.org/10.1080/00405848409543088

Ushioda, E. (1996). Learner Autonomy 5: The Role of Motivation. Dublin: Authentic.

Vygotsky, L.S. (1978) Mind in Society: the Development of Higher Psychological Processes. Harvard University Press.

Wang, L. (2007). Variation in learning styles in a group of Chinese English as a foreign language learners. International Education Journal, 2007, 8(2), 408-417. ISSN 1443-1475 (C) 2007 Shannon Research Press. http://iej.com.au 408.

Wilcoxson, L., \& Prosser, M. T. (1996). Kolb's Learning Style inventory: Review and further study of validity and Pr.liahilitv. The British Joumal of Educational Psychology, 66, 247-257.

Zhang, L.F., \& Sternberg, R.J. (2005). A threefold model of intellectual styles. Educational Psychology Review, 17(1), 2. http://dx.doi.org/10.1007/s10648-005-1635-4

Zhang, L.X. \& Li X.X. (2004). A comparative study on learner autonomy between Chinese students and west European students. Foreign Language World, 4, 15-23.

Table 1. Descriptive Statistics

Concerning Major Learning Style Preferences
\begin{tabular}{|c|c|c|}
\hline & Frequency & Percent \\
\hline Kinesthetic & 53 & 26.5 \\
Visual & 35 & 17.5 \\
Individual & 32 & 16.0 \\
Group & 31 & 15.5 \\
Auditory & 27 & 13.5 \\
Tactile & 22 & 11.0 \\
Total & 200 & 100. \\
\hline
\end{tabular}


Table 2. Descriptive Statistics

Concerning Minor Learning Style Preferences

\begin{tabular}{|c|c|c|}
\hline & Frequency & Percent \\
\hline Kinesthetic & 55 & 27.5 \\
Visual & 41 & 20.5 \\
Auditory & 35 & 17.5 \\
Group & 25 & 12.5 \\
Tactile & 24 & 12.0 \\
Individual & 20 & 10.0 \\
Total & 200 & 100 \\
\hline
\end{tabular}

Table 3. Descriptive Statistics on Autonomy Scores Based on Level

\begin{tabular}{|c|c|c|c|c|c|}
\hline Autonomy & $N$ & Min & Max & Mean & S.D \\
\hline Low Level & 97 & 44.00 & 71.00 & 64.6082 & 6.22283 \\
High Level & 90 & 73.00 & 93.00 & 77.9778 & 4.15967 \\
\hline
\end{tabular}

Table 4. Two-way ANOVA Results on the Relation between Learning Styles, Gender and Autonomy Level

\begin{tabular}{|c|c|c|c|c|c|c|}
\hline Language Learning Styles & Source & Type III Sum of Squares & $d f$ & Mean Square & $F$ & Sig. \\
\hline \multirow{3}{*}{ Visual } & Autonomy level & 6.332 & 2 & 3.166 & .099 & .906 \\
& Gender & .044 & 1 & .044 & .001 & .970 \\
& Autonomy level * gender & 55.624 & 2 & 27.812 & .870 & .421 \\
\hline \multirow{3}{*}{ Auditory } & Autonomy level & 12.323 & 1 & 12.323 & .482 & .488 \\
& Gender & 18.571 & 2 & 9.285 & .363 & .696 \\
& Autonomy level * gender & 5.374 & 2 & 2.687 & .105 & .900 \\
\hline \multirow{3}{*}{ Kinesthetic } & Autonomy level & 15.768 & 1 & 15.768 & .538 & .464 \\
& Gender & 4.150 & 2 & 2.075 & .071 & .932 \\
& Autonomy level * gender & 40.234 & 2 & 20.117 & .687 & .505 \\
\hline \multirow{3}{*}{ Tactile } & Autonomy level & 39.954 & 1 & 39.954 & 1.229 & .269 \\
& Gender & 64.242 & 2 & 32.121 & .988 & .374 \\
& Autonomy level * gender & 33.960 & 2 & 16.980 & .522 & .594 \\
\hline \multirow{3}{*}{ Group } & Autonomy level & 140.164 & 1 & 140.164 & 1.995 & .159 \\
& Gender & 130.757 & 2 & 65.379 & .931 & .396 \\
& Autonomy level * gender & 177.082 & 2 & 88.541 & 1.260 & .286 \\
\hline \multirow{3}{*}{ Individual } & Autonomy level & 33.734 & 2 & 16.867 & .194 & .824 \\
& Gender & 4.858 & 1 & 4.858 & .056 & .813 \\
& Autonomy level * gender & 179.460 & 2 & 89.730 & 1.031 & .359 \\
\hline
\end{tabular}


Table 5. Correlation between Participants' Autonomy and Learning Style Preferences in High Group

\begin{tabular}{|lcc|}
\hline Learning Style Preference & & Learners' Autonomy \\
\hline Visual & Pearson Correlation & .268 \\
& Sig. (2-tailed) & .011 \\
\hline Auditory & Pearson Correlation & .217 \\
& Sig. (2-tailed) & .040 \\
\hline Kinesthetic & Pearson Correlation & .171 \\
& Sig. (2-lailed) & .108 \\
\hline Tactile & Pearson Correlation & .207 \\
& Sig. (2-tailed) & .051 \\
\hline Group & Pearson Correlation & -.68 \\
& Sig. (2-tailed) & .526 \\
\hline Individual & Pearson Correlation & .008 \\
& Sig. (2-tailed) & .944 \\
\hline
\end{tabular}

Table 6. Correlation between Participants' Autonomy and Learning Style Preferences in Low Group

\begin{tabular}{|lcc|}
\hline Learning Style Preference & & Learners' Autonomy \\
\hline Visual & Pearson Correlation & -.088 \\
& Sig. (2-tailed) & .389 \\
\hline Auditory & Pearson Correlation & -.008 \\
& Sig. (2-tailed) & .939 \\
\hline Kinesthetic & Pearson Correlation & .62 \\
& Sig. (2-tailed) & .545 \\
\hline Tactile & Pearson Correlation & .077 \\
& Sig. (2-tailed) & .453 \\
\hline Group & Pearson Correlation & -.040 \\
& Sig. (2-tailed) & .700 \\
\hline Individual & Pearson Correlation & .080 \\
& Sig. (2-tailed) & .439 \\
\hline
\end{tabular}

Full Name (if possible):

\section{APPENDIX A}

Age:

Sex: $\quad$ Female $\quad$ Male

Date:

Major Field:

\section{Perceptual Learning Style Preference Questionnaire}

Directions: People learn in many different ways. For example, some people learn primarily with their eyes (visual learners) or with their ears (auditory learners); some people prefer to learn by experience and / or by "hands-on" tasks (kinaesthetic or tactile learners); some people learn better when they work alone, while others prefer to learn in groups.

This questionnaire has been designed to help you identify the way(s) you learn best - the way(s) you prefer to learn. Read each statement on the following pages. Please respond to the statements AS THEY APPLY TO YOUR STUDY OF ENGLISH. Decide whether you agree or disagree with each statement. 
Please respond to each statement quickly, without too much thought. Try not to change your responses after you choose them.

\begin{tabular}{|l|l|l|l|l|l|}
\hline Questionnaire Statements & $\begin{array}{l}\text { Strongly } \\
\text { agree }\end{array}$ & Agree & Undecided & Disagree & $\begin{array}{l}\text { Strongly } \\
\text { disagree }\end{array}$ \\
\hline
\end{tabular}

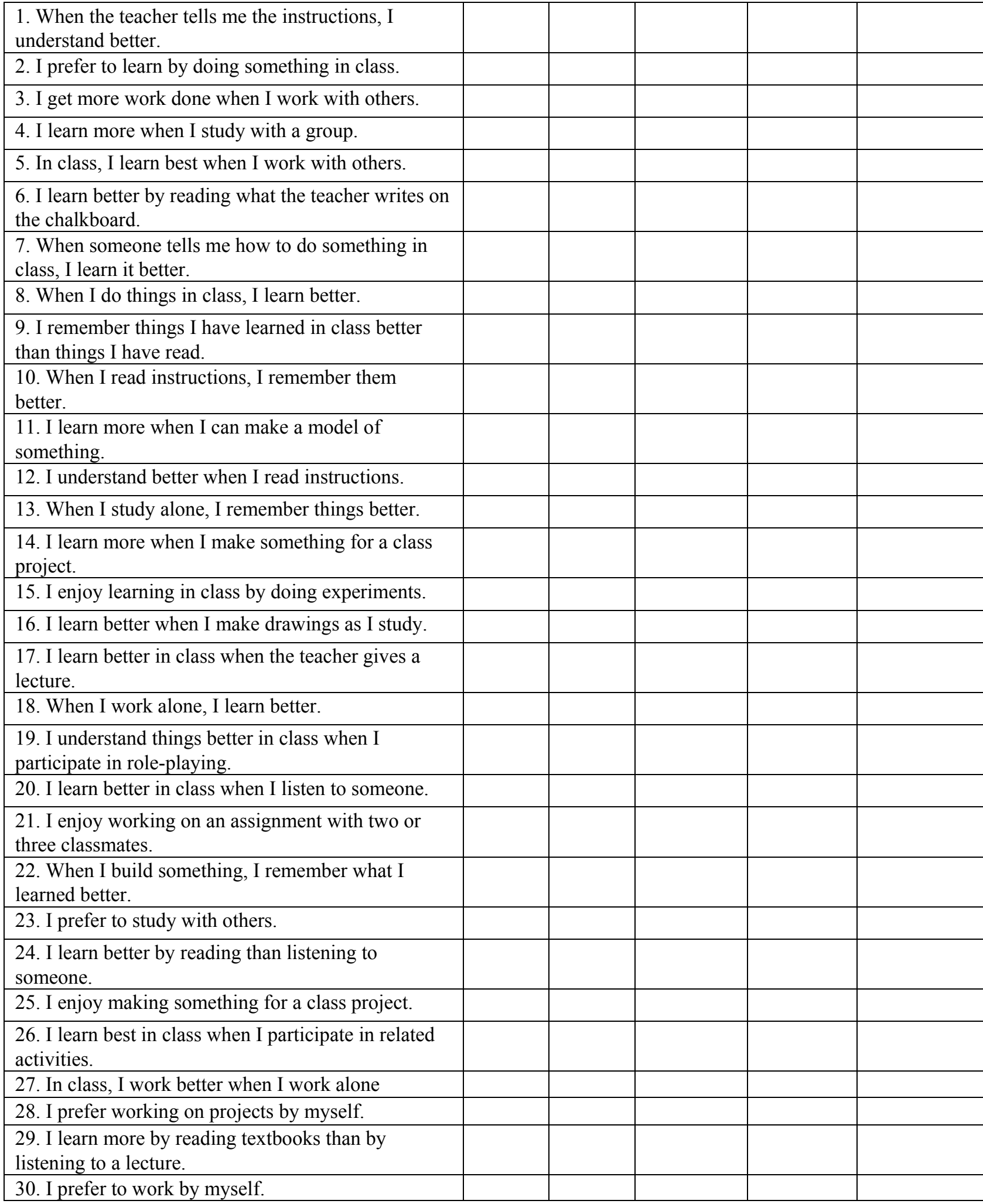


APPENDIX B

Questionnaires to investigate the Learner autonomy

Direction: In order to investigate the Learner autonomy, will you please circle the one closest answer to the following questions according to your true cases. Thank you very much for your help and patience!

Part I

\begin{tabular}{|c|c|c|c|c|c|}
\hline Questionnaire Statements & Never & Rarely & Sometimes & Often & always \\
\hline 1. I think I have the ability to learn English well. & & & & & \\
\hline 2. I make good use of my free time in English study. & & & & & \\
\hline 3. I preview before the class. & & & & & \\
\hline 4. I find I can finish my task in time & & & & & \\
\hline $\begin{array}{l}\text { 5. I keep a record of my study, such as keeping a } \\
\text { diary, writing review etc. }\end{array}$ & & & & & \\
\hline $\begin{array}{l}\text { 6. I make self-exam with the exam papers chosen by } \\
\text { myself. }\end{array}$ & & & & & \\
\hline $\begin{array}{l}\text { 7. I reward myself such as going shopping, playing } \\
\text { etc. when I progress. }\end{array}$ & & & & & \\
\hline $\begin{array}{l}\text { 8. I attend out-class activities to practice and learn th } \\
\text { language. }\end{array}$ & & & & & \\
\hline $\begin{array}{l}\text { 9. During the class, I try to catch chances to take par } \\
\text { in activities such as pair/group discussion, role-play, } \\
\text { etc. }\end{array}$ & & & & & \\
\hline $\begin{array}{l}\text { 10. I know my strengths and weaknesses in my } \\
\text { English study. }\end{array}$ & & & & & \\
\hline $\begin{array}{l}\text { 11. I choose books, exercises which suit me, neither } \\
\text { too difficult nor too easy }\end{array}$ & & & & & \\
\hline
\end{tabular}

\section{Part II}

12. I study English here due to:

1. my parents' demand

2. curiosity

3. getting a good job, help to my major

4. interest of English culture, such as film, sports, music, etc.

5. 3 and 4

13. I think the learner-teacher relationship is that of:

1. receiver and giver

2. raw material and maker

3. customer and shopkeeper

4. children and partners

5. explorer and director

14. I think my success or failure in English study is mainly due to:

1. luck or fate

2. English studying environment

3. studying facilities(aids)

4. teachers

5. myself

15. Whether students should design the teaching plan together with teachers

or not, my opinion is:

1. strongly agree

2. agree

3. neutral

4. oppose

5. strongly oppose 
16. When the teacher asks questions for us to answer, I would mostly like to:

1. wait for others' answers

2. think and ready to answer

3. look up books, dictionaries

4. clarify questions with teachers

5. join a pair/group discussion

17. When I meet a word I don't know, I mainly:

1. let it go

2. ask others

3. guess the meaning

4. 2 and 5

5. look up the dictionary

18. When I make mistakes in study, I'd usually like the following ones to correct them:

1. let them be

2. teachers

3. Classmates

4. Others

5. books or dictionaries

19. When I am asked to use technologies that I haven't used before(e. g. internet discussion),

1. I usually try to learn new skills

2. I learn them following others

3. I feel worried, but anyway

4. I put it off or try to avoid it

5. I resist using them

20. 1 think the following way is most useful in my English study:

1. taking notes

2. mechanic memory

3. doing exercises of grammar, translation, words etc.

4. classifying or grouping or comparing

5. group discussion

21. I usually use materials selected:

1. only by teachers

2. mostly by teachers

3. by teachers and by myself

4. mostly by myself

5. only by myself 